\title{
Comunicação e Semiótica: das mediações aos meios
}

Lucrécia D Alessio Ferrara

Programa de Pós-Graduação em Comunicação e Semiótica - PUCSP 


\section{Resumo}

Partindo de intencional inversão do título de conhecida obra de Jesus Matin Barbero "Dos Meios às Mediações comunicação, cultura, hegemonia", este trabalho estuda a relação epistemológica que se constitui entre sujeito e objetos científicos quando, em processo de evolução cultural e tecnológica, se substitui a mediação, de base linear e monovalente, pela interação que assume características complexas, circulares e polivalentes entre emissor e receptor ou entre mensagem e meios. A título de hipótese, propõe-se que, na ambiguidade que se estabelece entre mediações e meios, se evidencia a tensão entre sujeito e objetos científicos, entre conhecimento e senso comum, entre o "que" e o "como" das interações construídas pelos meios, entre teoria e método, entre comunicação como controle e semiótica disponível ao sentido.

\section{Palavras-chave}

ciência, mediações, meios, comunicação, semiótica

\section{Abstract}

In analyse the very important Jesus Martin Barbero work's named " Dos Meios às Mediações comunicação, cultura hegemonia" and in consider the technological, social and cultural nowadays revolution, we propose to invert the name of that work. In this way, the aim of this paper is to discuss a non linear communication process when we observe the interaction between sender and receiver, scientific subject and object, media and messages. We suppose who in the ambiguity relation between media and messages it is possible to find new dimension of knowledge, common sense, theory, method, communication and semiotics.

\section{Key words}

science, media, message, communication, semiotics. 


\section{Das mediações aos meios}

O título desse trabalho foi inspirado pela conhecida obra de
Jesus Martín Barbero "Dos Meios às Mediações Comu-
nicação Cultura Hegemonia" e, sobretudo, pela proposta de uma inversão - Das Mediações aos Meios - que o autor apresenta no prefácio da quinta edição espanhola da obra, apontando aquela inversão como necessidade imposta pela relação entre globalização, ufanismo tecnológico, políticas cuturais englobantes e, sobretudo, pela lógica do mercado que encontra, no desenvolvimento dos meios eletrico-eletrônico-digitais, condições estimulantes e adequadas para a ampliação e definitiva hegemeonia da indústria cultural. Contra as mediações, os meios surgem como elementos sedutores porque aptos a instrumentalizar a comunicação que serve aos níveis de decisão política, econômica e cultural.

Como se vê, entende-se, nessa formulação, que os meios surgem como ingênuos veículos transmissores submissos a ardilosas estratégias de mediação capazes de submeter a recepção, aliciandoa na sedução proposta pelos seus personagens, valores e idéias . Desse modo, entende-se que o receptor é um passivo depósito de informação, enquanto os meios surgem perfilados como instrumentos suficientes a serviço do neologismo "mídia" a quem cabe desenhar, articular e assegurar o contorno estável da passividade do receptor e, ao mesmo tempo, o modelo ontológico-funcional que entende a comunicação como transferência de um pólo a outro. 
Assim entendido, está óbvio que, ambos, o neologismo e o modelo se opõem à mediação chegando, até mesmo, a negar sua possibilidade de comunicação visto que, no controle funcional proposto, a comunicação, se minimiza e se reduz a um pacote de valores, slogans, modismos com os quais se propõe "massagear" o imaginário do receptor e controlar suas reações, ao mesmo tempo em que se manipula seus valores e comportamentos. Entretanto, a avassaladora e contínua revolução tecnológica dos meios levou à superação da ingênua hegemonia anterior e exigiu constatar que nenhuma mídia subsiste sem mediação que, na sua potencialidade relacional, evidencia que todo meio é o oposto da manipulação anterior.

Observa-se que a repulsa justificada pelo caráter midiático, que impregnou toda a indústria cultural e foi violentamente repelida pela Escola de Frankfurt e, notadamente, entre os alemães, por Adorno e Horkheimer e, na América Latina, pelo próprio Barbero, solidificou a interpretação da possibilidade comunicativa dos meios, considerando, apenas, sua atuação instrumental, em favor de uma passividade receptiva e de uma manipulação ideológica de duvidosa ética, submissa a interesses políticos e econômicos.

O equívoco dessa interpretação foi tão intenso que, frequentemente, se confunde meios com mídias quando, na revolucionária emergência dos meios tecnológicos, notadamente os digitais, se configurou a definitiva característica da sociedade da comunicação e da informação na gerência dos destinos econômicos do planeta, pretendidos pela globalização e acompanhados com sofreguidão pela mundialização da cultura. Confundir meios e mídias significa não compreender outra realidade comunicativa e cultural, distinta daquela construída pela comunicação manipulativa dos meios técnicos e voltada para a construção de uma sociedade maquínica e controlada no modo de pensar, nos seus valores e ações:

"Não são poucas as vozes que, nos últimos anos, convidaram-me a escrever um livro que respondesse à inversão do título, isto é Das mediações aos meios, pois este pareceria ser o novo rumo de que a investigação sobre as relações entre comunicação e cultura na América 
Latina está necessitando. Porém, por trás dessa proposta, se misturam visões do devir social e de projetos muito diferentes. Chego a vislumbrar pelo menos dois. Um que partindo da envergadura econômico-cultural que adquiriram as tecnologias áudio-visuais e informáticas nos acelerados processos de globalização, busca levar em conta os meios na hora de construir políticas culturais que façam frente aos efeitos dissocializadores do neoliberalismo e insiram explicitamente as indústrias culturais na construção econômica e política da região. $O$ outro projeto resulta da combinação do otimismo tecnológico com o mais radical pessimismo político, e o que busca é legitimar, através do poder dos meios, a onipresença mediadora do mercado." (Barbero, 2006:11)

Nesse quadro, não admira que a interpretação de Barbero reduza a comunicação à passividade de uma transmissão onde o meio está a serviço de um "agir estratégico", conforme foi proposto por Habermas. Desse modo e sintetizando, comunicação é transporte de informação, mediação é passividade receptiva e o meio é veículo técnico comandado, sem exceção, pelas diversas mídias. Reduz-se, portanto, a comunicação à transmissão de um código tecnológico; a mediação ao consumo cultural orquestrado politicamente pelo mercado e os meios são simples suportes entranhados em mediações lineares que vão do emissor cultural ao receptor disperso na massa uniforme e controlada pela redundância. Portanto, na singular unidade que vai dos meios às mediações, não cabe diferenças, antinomias ou complexidades.

Entretanto, no título proposto para esse trabalho "Das Mediações aos Meios" sugere-se uma inversão que não se reduz a uma troca de vocábulos, mas propõe uma sutil ordem que deve considerar a possibilidade de subverter o anterior conceito de comunicação enquanto transmissão, para substitui-lo pela interação que, sistêmicamente, cria um ambiente de informação sugerido pelos meios enquanto manifestação semiótica. Essa característica deixa evidente que meios são constituídos por signos e produzem linguagens 
que, independente da maior ou menor versatilidade tecnológica do instrumento que lhe dá suporte e, exatamente por isso, evidencia inesgotável capacidade de produzir interações, subjetividades, trocas entre igualdades não hegemônicas e, por isso, capazes de contemplar ou fazer surgir diferenças. De modo inalienável, esse movimento ocorre entre interações que se fazem dinâmicas, circulares, comunicativas e solidárias na produção de outras matrizes culturais que, na história, multiplicam a comunicação e a informação.

A confusa unidade que se construiu ao misturar meios e mídias impediu que, nos territórios políticos, técnicos e, sobretudo, epistemológicos da comunicação, se observasse que a mediação tende a se expandir e a superar as possíveis matrizes técnicas que a agenciam inicialmente e que tendem a ser substituídas rapidamente pela própria e vertiginosa mediação patrocinada pelos meios. Ou seja, assim como informação gera informação, comunicação gera mediação e meios. Observando aquela confusa unidade, entende-se que, na mencionada obra de Barbero, superar os meios é condição para atingir a única e adequada mediação cultural. Desse modo, parece que entre meios e mediações prevalece uma linearidade de causa e efeito que possibilita a suposta e inquestionável intervenção das mídias.

Entretanto, considerar a inversão proposta e produzir uma sobrevalência dos meios para transformar mediações em interações exige entender a comunicação como constituição de um macro ambiente natural, cultural e tecnológico em mútua impregnação para que seja possível efetivar a anterior circularidade interativa presente em todas as linguagens. Nela, as características técnicas e tecnológicas dos meios são também interativas, pois interferem no modo comunicativo, superando a subjetividade conteudística que, com frequência, impregna o conceito de mediação e, sobretudo, transforma o meio em simples veículo do próprio processo interativo.

Porém, deslocar o eixo do debate, fazendo-o migrar das mediações para os meios exige superar a comunicação centrada sobre a mensagem, para considerar os meios que a transmitem ou a estruturam enquanto signo capaz de caracterizar uma linguagem e, em continuidade, dar sentido cultural às variáveis históricas. Nessa radical metamorfose da compreensão dos meios, envolvem-se 
comunicação e semiótica. Porém passa-se a entender a semiótica como ciência que supera sua rígida, embora eficiente, estratificação metodológica, para considerar os meios nas singularidades da sua codificação sígnica e nas possíveis interfaces que podem ocorrer entre elas, gerando outros meios e interações como elementos inevitáveis que estão presentes no imprevisto emaranhado das redes culturais: a interação submete a mensagem à semiose dos signos que evidenciam um modo de comunicar em expansão. Entretanto, o processo que nos leva das mediações aos meios supõe submissões e revisões: da comunicação que deve considerar a interação para perceber que o receptor é co-gestor do processo comunicativo; e da semiótica que deve considerar a semiose de todos os signos e linguagens que relativiza os significados e impõe a percepção de que todos os enunciados constróem a cultura e são por ela construídos.

\section{Comunicação e Semiótica}

Embora a noção de signo ou de estrutura inteligível da realidade possa ser encontrada como base teórica indiscutível no Crátilo ou no Sofista de Platão e, sobretudo, na Poética e na Retórica de Aristóteles, é possível encontrar, no território da filosofia, uma constante semiótica quando se deixa de considerar a linguagem de âmbito exclusivamente linguístico para convertê-la em questão lógica.

Esse foi o eixo da conferência apresentada por Roman Jakobson na sessão de abertura do Primeiro Congresso da Associação Internacional de Semiótica realizado em Milão em junho de 1974. Embora reportando-se a Saussure e a Peirce como os epígonos modernos da semiótica, Roman Jakobson procura, nas duas teorias, as bases lógicas que poderiam conceituar a Semiótica e justificar sua evolução.

Em clara base filosófica e lógica, Peirce vai buscar as raízes do seu sistema em filósofos do passado e, segundo Jakobson, em John Locke no século XVII e na obra fundamental denominada Ensaios sobre o Conhecimento Humano. Dentro de um âmbito rigorosamente linguístico, Saussure e outros que continuaram sua obra como Hjelmslev, o maior destaque teórico é dado para uma 
estrutura da língua montada sobre características gerais do signo como arbitrariedade, necessidade e universalidade e, como consequência, à revelia do objeto de referência. Um conceito de linguagem como sistema fechado caracterizado pela precisão de valores de cada parte em relação ao conjunto sistêmico do qual cada uma depende.

Entretanto, estudando não propriamente um conceito de semiótica, mas seu desenvolvimento, Jakobson elabora arguta observação ao comparar, mas não em contrapor, Peirce e Saussure. Nessa comparação, não só Peirce e Saussure são apontados, cada um a seu modo, como origens da semiótica moderna, mas sobretudo, Jakobson procura, nos meandros da teoria de Saussure, os elementos que poderiam levar a pensar, não na dicotomia entre semiologia e semiótica, mas no modo de encontrar, nos dois autores, as bases fundamentais de uma só teoria que, como ciência unificada e interdisciplinar, surge no cerne de ciências que se voltam para objetos distintos que vão das estruturas culturais e históricas da sociedade para, passando pelas manifestações artísticas, atingir a complexa estrutura das relações comunicantes entre a mente, a cultura e a natureza.

A Peirce, Jakobson reconhece o saber

"organizar os argumentos conclusivos e desobstruir o terreno para erigir, por sua conta e risco, o edificio da ciência que foi antecipada e entrevista há dois séculos, pelo pensamento filosófico europeu" (Jakobson, 1978: 42);

e a Saussure, Jakobson atribui o reconhecimento da Semiótica:

"em todos os níveis e aspectos da linguagem, a relação recíproca entre as duas faces do signo o significante $e o$ significado permanece válida, mas é evidente que o caráter de significado e a estruturação do significante mudam conforme a natureza do fenômeno lingüístico. Dos traços distintivos até a totalidade do discurso, as entidades linguísticas, não obstante as respectivas 
diferenças de estrutura, de função e de dimensão, devem ser entendidas como objeto de uma ciência comum $e$ única, a semiótica." (Jakobson, 1978: 53-54)

O confronto entre as duas citações permite observar que, para Peirce e para Saussure, a ciência dos signos compõe o universo da cultura e vai além da simples e metodológica escansão compositiva dos enunciados sígnicos, dando origem, portanto, a uma outra ciência que se ocuparia desse domínio mais amplo e complexo de âmbito cultural e cognitivo.

Porém, além dessa relação que permite a Jokobson aproximar, com argúcia, as bases de uma só ciência que tendia a apresentar-se em dois ramos dicotômicos, observa-se, sobretudo para aquilo que interessa a esse trabalho, outra afirmação contundente colhida em uma nota de Saussure para um estudo sobre Whitney, datado de 1894 e estudada em trabalho anterior, porém com características distintas( Ferrara, 2007):

"esta será a reação fundamental para o estudo da linguagem na teoria dos signos, abrir um horizonte nunca entrevisto, ensinando e revelando um lado totalmente novo do signo, isto é, aquele que diz que ele não começa a ser realmente conhecido, senão quando é considerado, não apenas como coisa transmissível mas, pela sua própria natureza, destinado a ser transmitido." (Jakobson, 1978: 49)

Esta citação ilumina do âmago da propria semiologia de Saussure, a relação contundente que se estabelece entre signo e meio e é capaz de revelar, em ambos, idêntica essência: um signo, como a um meio, não cabe transmitir, mas ser transmitido no modo específico de um meio que, como pele do signo, é, ao mesmo tempo, elemento constitutivo de toda mediação comunicativa e exterioridade semiótica que permite transformar a mediação em dinâmica cognição, que repele o significado de matriz logocêntrica e antropomórfica. 
Nessa visão abrangente do signo e do meio, não cabe embutirlhes significados determinados "a priori”, visto que não são simples recursos instrumentais, ao contrário, é imperioso identificá-los na dubiedade entre o modo essencial de ser signo ou meio e o objeto que representam ou transmitem: a um signo ou meio não cabe apenas representar ou transmitir, mas o modo como o fazem, permite distinções no modo como constróem aquela transmissão e, nela, criam outras realidades culturais em semiose. Se a um signo cabe construir contornos e desenhos imediatamente perceptíveis, à transmissão cabe traduzir um significado ou sentido inerente ao objeto do signo. Está aberta a relação inerente a todos os processos sígnicos e comunicativos e largamente estudados por Lotman quando relaciona signo e transmissão a uma invariante denominada código:

"Por conseguiente, la presencia de un código es considerada como algo precedente. A esa suposición está ligada la idea del lenguaje como un sistema cerrado que es capaz de generar una multitud abierta de textos, que se multiplica infinitamente." (Lotman, 1996:92)

Como se observa e considerando-se o caráter fechado da linguagem, parece haver uma contraposição entre ela e um texto transmitido, porém em nota esclarecedora, o próprio Lotman observa a possibilidade de dúvida em relação àquele caráter. Desse modo, linguagem e textos da cultura são imediatamente interdependentes, como o são um signo e o meio através do qual se transmite e se comunica. Desse modo, a natureza transmissível de um signo só se realiza na semiose dos textos que o comunicam:

"La correlación entre el texto y el código ( el lenguage) cambia. Al tomar consciencia de algún objeto como texto, con ello estamos suponiendo que está codificado de alguma manera; la suposición del carácter codificado entra en el concepto de texto. Sin embargo, ese código mismo nos es desconocido: todavia tendremos que reconstruirlo basándonos en el texto que nos es dado." (Lotman, 1996: 93) 
Processa-se, portanto, entre um signo e o meio que o transmite uma só relação que os congrega enquanto comunicação e os assinala no espaço da cultura, desse modo, todo signo é testemunha do momento técnico e cultural que o nutre e constitui, estabelecendo uma irrecusável aliança entre semiótica e comunicação:

"Sin embargo, no se provocarían las consecuencias catastróficas si se tratara sólo del progreso técnico: el estudio muestra que las grandes revoluciones científicotécnicas se entrelazan invariablemente con revoluciones semióticas que cambian decididamente todo el sistema de la semiótica sociocultural. Ante todo, se ha de senãlar que el mundo material que rodea al hombre, que llena su espacio cultural, tiene no sólo una función practica, sino también una función semiótica. El brusco cambio en el mundo de las cosas cambia la actitud hacia las normas acostumbradas de apropiación semiótica del mundo." (Lotman, 1996: 233)

Portanto, em textos da cultura, um signo ou meio nada transmitem, mas se transmitem, gerando um contexto comunicativo onde interagem homens, natureza, mente e cultura que se percebem como elementos conectados e consequência da natureza cultural de um modo específico de ser signo ou meio, tecnológio ou não. Reinventa-se ou revisita-se "O meio é a mensagem" de Mcluhan e a partir da lúcida citação que nele próprio se pode colher:

"Quando digo que o meio é a mensagem, estou dizendo que o automóvel não é um meio. Noutras palavras, o meio do carro é constituído pelos efeitos do carro. Quando se eliminam os efeitos, o significado do carro desaparece... Assim "o meio é a mensagem" não é uma simples observação, e sempre hesitei em explicá-la. Significa realmente um ambiente oculto de serviços criados por uma inovação, e o ambiente oculto de serviços é o que muda as pessoas. $O$ que muda as pessoas é o ambiente, não a tecnologia" (Mcluhan, 2005: 284) 
Desse modo, se de um lado, o significado de um signo não é inerente ao objeto que representa ou substitui, mas, ao contrário, produz-se como conseqüência específica de um modo também singular de representar, de outro lado, um meio nada transmite, mas cria, pelo seu modo de ser, uma interação que lhe é consequiente. Assim, cria-se uma operativa simetria entre signo e meio, entre representação e interação e a citação de Mcluhan sugere a possível inversão do título da obra de Barbero, além de deixar claro que os meios, acompanhando a semiose dos signos, organizam-se, trasformam-se nos processos interativos e transitam no espaço da cultura, constituindo-o.

Situadas entre o signo e o meio, exige-se que a semiótica e a comunicação subvertam seus pressupostos tradicionais: à comunicação exige-se abandonar a linearidade funcional e intrumental que parte da atividade do emissor para circunscrever a passividade do receptor; à semiótica exige-se abandonar a instrumentação metodológica que disciplina a análise e submete o significado à imanência dos próprios recursos do método e à hermenêutica do sentido. Nessa subversão, ambas, comunicação e semiótica são obrigadas a abandonar o roteiro das mediações pressupostas para aderir à interação que, na sua reiterada circularidade, transforma o modo de ser signos ou meios em elementos de uma semiótica comunicativa.

Em trabalho anterior (Ferrara, 2007), sugeri ultrapassar o caráter designativo dos substantivos comunicação e semiótica e os transformei em verbos para explicitar a ação que subjaz aos substantivos. Essa operação parece ser necessária para explicitar o processo de simetria que leva à geração de um significado, a partir do modo específico de ser signo ou do efeito de um meio como elementos detonadores de uma nova comunicação, gerada pelos meios, evidenciados semioticamente.

Nos dois casos, emerge a operação relacional que só pode ser produzida por uma mente interpretadora que atua na continuidade dos processos de significação e dos efeitos comunicativos e semióticos. Nos dois casos, surpreendemos uma estreita complementaridade entre comunicação e semiótica, integradas em diálogo que surge como 
matriz do próprio processo de semiose como produção de sentidos e interpretações que sustentam relações e vínculos comunicativos. Portanto, se sem semiose não há semiótica, sem diálogo e interação não há comunicação e, em consequência, sem semiótica não há comunicação e, sobretudo, cognição comunicativa através dos signos que a sustentam.

\section{Comunicar e Semiotizar}

Aparentemente e se os tomarmos separadamente, os dois verbos insinuam que seu emprego está diretamente relacionado à transmissão e produção de significado, ou a método e instrumento de análise, ou ainda, a produto acabado para atingir efeitos precisos e práticos. Entretanto esses possíveis significados dão origem a uma tensão marcante e de dimensões distintas àqueles verbos.

Tradicionalmente, considerar o meio nos levou a perceber sua maior ou menor eficiência instrumental no transporte da mensagem, mas se considerarmos as mediações e seus processos interativos, aquela eficiência pode não ser válida ou ser bastante relativizada. Isto que dizer que meios e mediações não se processam de modo linear, monovalente ou programado. Se o comunicar subjacente à mensagem tende a apresentar-se de modo exaustivo e monocórdico, ele impede ou abafa a caracteristica dialogante do contínuo que dá origem às tensões e transformações culturais, impedindo, portanto, que a entonação semiótica dos meios se faça audível. Ao contrário, se superarmos a dicotomia tradicional que se observa entre meio e signo ou entre comunicação e semiótica, observeremos que, em processo, eles assinalam o ambiente interativo que, cada vez mais e como consequência inalienável das próprias tecnologias da comunicação, constitui a realidade social e cultural dos nossos dias, apontada por Sodré( 2003) como o novo ambiente biosmidiático. Nessa realidade, é possivel observar que, se não há comunicação sem semiótica, também não há semiótica que se estruture na singularidade sígnica. Fora dessa dinâmica, sobra um descompasso que reduz a comunicação a uma operação estática e corriqueira que desconhece o caráter processual e complexo inerente 
ao reconhecimento dos vínculos que consolidam o caráter transmissível no contínuo cultural inerente à propria natureza dos meios.

Portanto, enquanto contínuo cognitivo, a semiose exige a vitalidade das duas ações: comunicar e semiotizar. Nesse processo, a tensão está contida, não no conteúdo da comunicação, mas em um modo semiótico de comunicar, onde o signo e o meio nada transmitem, mas se transmitem. Quanto se inverte a relação entre meios e mediações, deixando aos meios técnicos, aos seus signos e linguagem a capacidade de transmitirem-se para comunicar, se reequacionam as constantes que subjazem ao comunicar e ao semiotizar e, ao mesmo tempo, se insinua radical mudança epistemológica que atinge as duas ações.

\section{A epistemologia do comunicar nas estratégias contínuas do semiotizar}

4.1. Ao transformar a mensagem em um modo contínuo de comunicar, estamos assumindo que esse signo ou meio técnico se apresenta de modo ambiguo porque, enquanto representação, não o faz por semelhança, mas sobretudo e ao contrário, como distância ou como diferença. Acrescenta ao mundo um outro comunicar que supera o conteúdo estático da mensagem, para alargar-se ou multiplicar-se na constituição do volume cognitivo que vai do homem à natureza ou da mensagem à cultura e aos seus significados em processo expansivo.

4.2. No comunicar, essa multiplicação supera a hegemonia de um emissor individual, coletivo ou institucional que, em linearidade mediativa ou em reversibilidade de causa e efeito, subjuga o destinatário condenado à inercia da ação meramente receptiva. Ao contrário, no semiotizar, exige-se que o signo seja considerado na sua espessura representativa que se expande em continuidades interpretativas e complexas, e não se reduzem à hermenêutica de um método adrede preparado para sua aplicação. Ao contrário, essa hermenêutica se expande na heurística que, em metalinguagem, transcodifica e questiona todos os métodos que se requalificam teoricamente, ao serem confrontados com a manifestação concreta 
de um modo de transmitir. Se, no comunicar, se tangenciam emissor e receptor para se superarem em constante e circular troca de papeis; no semiotizar, o meio técnico expandido em signo, não se restringe à sólida e estrutural base de todos os métodos mas, subvertendo-os, se apresenta em semiose para construir um ambiente comunicativo que se expande na natureza e consolida a cultura, concretizando as premissas teóricas de Peirce e de Saussure:

"Se Peirce introduz, ao lado da noção de signo como representação ou mediação, o conceito de interpretante, Saussure aponta, ao lado de um signo com análogo desempenho, o conceito de valor. De um lado, o interpretante de Peirce supõe tudo aquilo que está implícito na própria maneira de ser signo, no proprio modo como o signo se estrutura enquanto representação e que o torna disponivel à interpretação no seu próprio desenho; de outro lado, a noção de valor de Saussure supera a frágil compreensão do signo enquanto estrutura invariável e arbitrária, para propor uma outra dimensão relacional intrínseca à componibilidade do signo, estabelecendo que sua identidade só se define quando é enfrentada em relação de continuidade, como propõe Lotman, com o sistema do qual faz parte e que lhe confere "seu real valor" entendendo-se como o conceito saussureano supera o caráter arbitrário do signo, para conferir-lhe identidade sistêmica" (Saussure, 1969: 246; Todorov-Ducrot, 1972: 32; Jakobson, 1978: 50. Ferrara, 2007: 144)

4.3. Entretanto, comunicar e semiotizar vêm-se subjugados por incondicional imprecisão. De um lado, na circularidade que se processa entre emissor e receptor, a comunicação se apresenta ambigua na sua origem e vacilante nos seus objetivos pois, sem desenho preciso, flutua nas redes culturais que se tecem cada vez mais intensamente, à medida em que se sedimenta uma sociedade da comunicação. De outro lado, os meios técnicos e os signos que aquela sociedade 
engendra vêm-se profundamente atingidos pelo constante e irreversível processo social e cultural que decorre dos avanços tecnológicos e determina outros valores e outros comportamentos. Nos dois casos, o comunicar e o semiotizar caracterizam-se como ações submissas a uma operação epistemológica pouco precisa porque se referem a um objeto científico que se apresenta de modo indeterminado e frágil que, embora capaz de estimular argutas e imprevisíveis interpretações, se apresenta de modo vulnerável e falível. Essa fragilidade que repele o consenso normativo do método, se justifica porque, nos dois casos, não há teorias ou métodos que os qualifiquem de antemão; ao contrário, ambos, teorias e métodos são, também, igualmente vulneráveis e falíveis, como características gerais do conhecimento apontadas por Peirce e citada por Vattimo ao identificar uma "comunidade ilimitada da comunicação":

"Agora torna-se evidente que, por um lado, o sujeito do possível consenso com a verdade da ciência não é uma "consciência em geral" extramundana, mas sim a sociedade histórico-real; mas que, por outro, a sociedade histórico-real só pode ser adequadamente compreendida se for considerada como objeto virtual da ciência, incluindo a ciência social, e se a sua relidade histórica for sempre reconhecida, do modo ao mesmo tempo empírico e normativo-crítico, em referência ao ideal, a realizar na sociedade, da comunidade ilimitada da comunicação" (Vattimo, 1992:27)

4.4. Essa indefinição epistemológica se adensa se considerarmos que, pela lógica, em uma sociedade da comunicação, vive-se imerso em signos e informações que dão, ao comunicar e ao semiotizar, outras e reais condições de reconhecimento do novo ambiente cultural. Desse modo, exige-se daquelas ações, a indispensável flexibilidade operativa e cognitiva, capaz de considerar que, em semiótica, comunicam-se os homens, a sociedade, a política e a cultura e, em fronteiras, todos se espelham, embora se relativizem a cada novo processo interativo. Nessa dinâmica, comunicação e semiótica se superpõem, mas a ambas se faz exigências, agora irrecusáveis. 
Da comunicação exige-se perceber que os meios não são instrumentos a serviço da linearidade mediativa como imaginava a indústria cultural repelida pela Escola de Frankfurt; da semiótica exigese considerar que os signos são moventes à medida em que sofrem a descontinuidade fenomenológica da alteridade presente em cada mediação, porém enquanto capacidade sígnica e representativa, essa descontinuidade tende a ser superada em novas e reabilitadoras representações sígnicas e enunciativas. Desse modo, nos dois casos, exige-se considerar que as interações correspondem a fases processuais marcadas pela alteridade que não esgota o processo ou a capacidade sígnica do meio que, comunicador por excelência, se expande semióticamente, utilizando-se ou não das técnicas e tecnologias que lhe estão disponíveis.

\section{Referências bibliográficas}

BARBERO, Jesús Martín. 2006. Dos Meios às Mediações. Rio de Janeiro: Ed.UFRJ.

BARBERO, Jesús Martín." Globalização comunicacional e transformação cultural" em Por uma Outra Comunicação (org. Denis de Moraes). 2003.Rio de Janeiro: Record.

FERRARAS, Lucrécia. 2007. "Comunicar e Semiotizar" em Cenários, Teorias e Epistemologias da Comunicação ( Jairo Ferreira, org). Rio de Janeiro: e-papers.

JAKOBSON, Roman. 1978. Lo Sviluppo della Semiotica. Milão: Bompiani.

LOTMAN, Yuri. 1996. La Semiosfera I Semiótica de la cultura y del texto (org. Desiderio Navarro). Madrid: Cátedra.

McLUHAN, Marshall. 1969. Mcluhan por Mcluhan entrevistas $e$ conferências inéditas do profeta da globalização (org. Stephanie Mcluhan e David Staines). Rio de Janeiro: Ediouro. SODRÉ, Muniz. 2002. Antropológica do Espelho Uma teoria da comunicação linear e em rede. Petrópolis: Vozes.

VATTIMO, Gianni. 1992. A Sociedade Transparente. Lisboa: Relógio D’Água. 